\title{
COMPLIMENT RESPONSES IN ENGLISH MADE BY SEVENTH GRADE STUDENTS OF SMPN 8 SEKAYU
}

\author{
1Paidi Gusmuliana \\ Institut Agama Islam Negeri Curup \\ paidigusmuliana@gmail.com \\ ${ }^{2}$ Eka Apriani, \\ Institut Agama Islam Negeri Curup \\ ekaapriani_90@ymail.com \\ ${ }^{3}$ Dadan Supardan \\ Universitas Islam Negeri Mataram \\ dadan.supardan@uinmataram.ac.id \\ ${ }^{4}$ Syafryadin \\ Universitas Bengkulu \\ Syafryadin@unib.ac.id \\ ${ }^{5}$ Hadi Suhermanto \\ Institut Agama Islam Negeri Curup \\ Hadi13nov74@gmail.com
}

\begin{abstract}
This paper showed the compliment responses in English made by $7^{\text {th }}$ grade students at SMP Negeri 8 Sekayu. The sample of this study was five females and five males of the $7^{\text {th }}$ grade students. From the seven categories of compliment responses, there were only six compliment responses in English made by students: acceptance, positive elaboration, neutral elaboration, denial, smiling, and no response. The result of this study showed that: 1) female had highest percentage in positive elaboration and smiling; 2) male had highest percentage in denial and no response; and 3) female and male had same percentage in acceptance and neutral elaboration response. There was no negative elaboration response used by students (female and male). Hence, it can be said that students gender hold important effect in giving compliment responses in English.
\end{abstract}

Keywords: Compliment Responses in English, $7^{\text {th }}$ grade students, SMP Negeri 8 Sekayu

\section{INTRODUCTION}

Compliments and compliment responses have significant aspect in sociolinguistic. According to Kim (2002), compliment is a particularly speech act to investigate when comparing cultures because it acts as a window through which we can view what is the valued in a particular culture. Goffman (1967; Bruti, 2006 cited in Morales, 2002) argues that compliments are primarily aimed at maintaining, enhancing, or supporting the addressee's face and are used for a variety of reasons, the most significant of which is perhaps to express admiration or approval of someone's work. 
Compliment is a part of politeness theory. The study of compliment and compliment responses have become a significant aspect of politeness theory (Morales, 2010). Politeness is a means for people to keep positive and negative face (Hiroko, 2002). The politeness is a strategy to keep faces for both parties (Yuhuan, 1997). It means that compliment and compliment responses are very important for the people to show their character, politeness. Cedar (2006) states that seven categories of compliment responses: acceptance, positive elaboration, neutral, elaboration, negative elaboration, denial, and no response. From the categories above, not all of compliment responses were used by the students of Native English, EFL and ESL.

Compliment responses in Native English are different from EFL (Falasi, 2006) and ESL (Han, 1992). It is caused by many aspects, especially in language use and culture. In EFL country, specifically in Indonesia, the government has already embedded the compliment materials in the curriculum. In the curriculum, the teacher should teach the students about expressing politeness: greeting, gratitude, apologizes, forbidding doing something, and asking to do something. Compliment responses are taught in the first semester of the $7^{\text {th }}$ grade students. So, it can be concluded that the government believes that politeness aspects, especially compliment, can make our students' characters will be better than before.

From the explanation above, the writer will observe the compliment responses in English made by junior high school students. As we know that, there is no study about compliment responses in English made by $7^{\text {th }}$ grade students at SMP Negeri 8 Sekayu. The major research questions of this research are as follows: (1) what are the compliment responses in English made by $7^{\text {th }}$ grade students of SMP Negeri 8 Sekayu?; (2) Does gender difference affect the compliment responses in English made by $7^{\text {th }}$ grade students of SMP Negeri 8 Sekayu?

\section{METHOD}

The researchers used a qualitative study. It means a reesearch focus in describing any sutuation or condition in population, systematically, factually, and accurately (Zuriah, 2007: 47). Population is a group of elements or cases, whether individuals, objects, or events, that conform to specific criteria and to which we intend to generalize the result of the research (McMillan, 1992). This study was conducted at SMPN 8 Sekayu, South Sumatera Province. The population of this study was the $7^{\text {th }}$ Grade students consist of four classes.

Table 1. Data of the 7th Grade Students of SMP N 8 Sekayu

\begin{tabular}{|l|l|l|}
\hline NO & CLASSES & NUMBER OF STUDENTS \\
\hline 1 & VII.1 & $37(\mathrm{M}=20, \mathrm{~F}=17)$ \\
\hline 2 & VII. & $37(\mathrm{M}=17, \mathrm{~F}=20)$ \\
\hline 3 & VII.3 & $35(\mathrm{M}=17, \mathrm{~F}=18)$ \\
\hline 4 & VII.4 & $36(\mathrm{M}=17, \mathrm{~F}=19)$ \\
\hline \multicolumn{2}{|l|}{ Total } & 145 Students \\
\hline
\end{tabular}

Purposive sampling technique was used in this research. The students was selected based on some criteria: (1) the students were taught by the same teacher, (2) the students did not take extra courses, (3) the students had the same number of 
teaching sessions at the same level, and (4) the students were selected based on the students result of English achievement test.

Table 2. The Students Score Level in Semester Examination

\begin{tabular}{|l|l|l|l|l|l|}
\hline \multirow{2}{*}{ NO } & \multirow{2}{*}{ CLASSES } & \multicolumn{3}{|l|}{ English Score Level } & Total \\
\cline { 3 - 5 } & & Low & Moderate & High & \\
\hline 1 & VII.1 & 28 & 4 & 5 & 37 \\
\hline 2 & VII.2 & 28 & 7 & 2 & 37 \\
\hline 3 & VII.3 & 27 & 6 & 2 & 35 \\
\hline 4 & VII.4 & 31 & 4 & 1 & 36 \\
\hline Male & 59 & 7 & 5 & 71 \\
Female & 55 & 14 & 5 & 74 \\
\hline \multicolumn{2}{|l|}{ Total } & 114 & 21 & 10 & 145 \\
\hline
\end{tabular}

The number of students involved in the study are 10 students out of 145 students who got similar English score category based on the result of English achievement test. The sample was chosen from High category score of students' English achievement. It was done because the writer would like to analyze students compliment responses in English so the sample should have a good score in English. There were five males and five females in this research.

The data was collected by using interview and an observation note. According to Nasution (2003: 34), interview is verbal communication to get information. Meanwhile, observation used to get the real condition of an activity and to get more accurate data (Setiadi, 2006: 204). There were five compliment responses categories analyzed by using interview: acceptance, positive elaboration, neutral, elaboration, negative elaboration, denial. However, there were two compliment responses categories analyzed by using observation note: smiling and no response.

1. Interview: The students were interviewed to get the data about their compliment responses in English. Every student (10 students) was interviewed by the writer one by one. The compliment responses interview is as follows:

Table 3. Compliment Responses Interview

\begin{tabular}{|l|l|}
\hline No & Compliment \\
\hline 1 & What is your name? It is a beautiful name. \\
\hline 2 & $\begin{array}{l}\text { I like your chin. Your chin is like Nikita Willy/ David } \\
\text { Beckham. }\end{array}$ \\
\hline 3 & $\begin{array}{l}\text { I like your black/ brown eyes. Your eyes is like my mother } \\
\text { has. }\end{array}$ \\
\hline 4 & $\begin{array}{l}\text { Is your ear look like your mother or father? I like your } \\
\text { big/small ear. }\end{array}$ \\
\hline 5 & $\begin{array}{l}\text { What shampoo do you use? I like your curly/straight/wavy } \\
\text { hair. }\end{array}$ \\
\hline 6 & $\begin{array}{l}\text { I like your Pointed/ Flat nose. There is not many people have } \\
\text { nose like you. }\end{array}$ \\
\hline 7 & \begin{tabular}{l} 
Your face is so quite/chubby. I like your oval/ round face. \\
\hline
\end{tabular} \\
\hline
\end{tabular}




\begin{tabular}{|l|l|}
\hline 8 & $\begin{array}{l}\text { How often do you brush your teeth? What is the name of your } \\
\text { toothpaste? I like your teeth. Your teeth are so clean. }\end{array}$ \\
\hline 9 & $\begin{array}{l}\text { Do you like your lips? I like your thin/ thick lips too. Your } \\
\text { lips are so sexy. }\end{array}$ \\
\hline 10 & $\begin{array}{l}\text { What is your favorite food? What is the food that makes your } \\
\text { body look like this? Ilike your slim/fat/skinny body. I will try } \\
\text { the food. }\end{array}$ \\
\hline
\end{tabular}

2. Observation note was used to find out students compliment responses categories: smiling and no response. This note was used to know the students gesture or expressing when they give a non-verbal compliment responses.

3. Smiling and No Response

Table 4. Smiling and No Response

\begin{tabular}{|l|l|}
\hline Smiling & No Response \\
\hline Smile \& Laugh & Silent \\
\hline
\end{tabular}

The data form interview and observation note were calculated by using percentage analysis. Percentage analysis was used to make a percentage of each compliment responses in English for each category. From this analysis, we can know the highest and lowest percentage of compliment responses category done by the students. The percentage analysis formula is as follows:

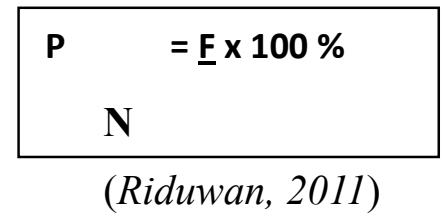

Where:

$\mathrm{P} \quad$ : Percentage

F : : Total of Students Compliment Responses

$\mathrm{N} \quad$ : Maximum Score

\section{RESULTS AND DISCUSSION}

The result of this study is divided into two categories: 1) students compliment responses in English and 2) the differences of gender in compliment responses in English.

\section{Students Compliment Responses in English}

The result of students' compliment responses in English for each student and question (1-10) is as follow: 
Table 5. Students Compliment Responses in English

\begin{tabular}{|c|c|c|c|c|c|c|c|c|c|c|}
\hline \multirow[t]{2}{*}{ Students } & \multicolumn{10}{|c|}{ Questions } \\
\hline & 1 & 2 & 3 & 4 & 5 & 6 & 7 & 8 & 9 & 10 \\
\hline 1 & $\mathrm{AC}$ & $\mathrm{NE}$ & NET.E & NEG.E & PE & D & D & $\mathrm{D}$ & D & $S$ \\
\hline 2 & $\mathrm{AC}$ & $\mathrm{AC}$ & NET.E & NET.E & PE & $S$ & PE & NET.E & NR & $S$ \\
\hline 3 & $\mathrm{D}$ & $\mathrm{D}$ & $\mathrm{AC}$ & $\mathrm{PE}$ & $\mathrm{D}$ & NET.E & $\mathrm{D}$ & $\mathrm{S}$ & NR & NR \\
\hline 4 & NET.E & $\mathrm{S}$ & $\mathrm{AC}$ & $\mathrm{S}$ & NR & NR & $\mathrm{S}$ & $\mathrm{D}$ & $\mathrm{S}$ & $\mathrm{S}$ \\
\hline 5 & $\mathrm{AC}$ & $\mathrm{S}$ & NET.E & $\mathrm{S}$ & NR & NR & NR & NR & $\mathrm{S}$ & $\mathrm{S}$ \\
\hline 6 & $\mathrm{~S}$ & NR & $\mathrm{AC}$ & $\bar{D}$ & $\mathrm{D}$ & $\mathrm{S}$ & $\mathrm{D}$ & $\mathrm{S}$ & NR & NR \\
\hline 7 & $\mathrm{AC}$ & $\mathrm{AC}$ & NET.E & NET.E & PE & $\mathrm{D}$ & $\mathrm{D}$ & $\mathrm{D}$ & $\mathrm{S}$ & NR \\
\hline 8 & $\mathrm{AC}$ & $\mathrm{AC}$ & NET.E & NET.E & $\mathrm{AC}$ & $\mathrm{D}$ & $\mathrm{D}$ & NET.E & $\mathrm{D}$ & NR \\
\hline 9 & $\mathrm{~S}$ & $\mathrm{~S}$ & NET.E & $S$ & $\mathrm{~S}$ & NR & $\mathrm{AC}$ & $\mathrm{D}$ & $\mathrm{S}$ & NR \\
\hline 10 & $\mathrm{~S}$ & $\mathrm{D}$ & NET.E & NET.E & $\mathrm{PE}$ & $\mathrm{S}$ & NR & NR & NR & NR \\
\hline
\end{tabular}

Note:

\begin{tabular}{|c|c|}
\hline $\mathrm{AC}$ & $=$ acceptance \\
\hline $\mathrm{PE}$ & $=$ positive elaboration \\
\hline NET.E & $=$ neutral elaboration \\
\hline NEG.E & $=$ negative elaboration \\
\hline $\mathrm{D}$ & $=$ denial \\
\hline & $=$ smiling \\
\hline NR & $=$ no response \\
\hline
\end{tabular}

From the table above, the data was calculated into percentage. The percentage of students compliment responses in English in each category (1-7) is as follow:

Table 6. The Percentage of Student Compliment Responses in English

\begin{tabular}{|c|c|c|c|c|c|c|c|}
\hline \multirow[t]{2}{*}{ Students } & \multicolumn{7}{|c|}{ Compliments Responses } \\
\hline & $\begin{array}{l}\text { Acceptan } \\
\text { ce }\end{array}$ & $\begin{array}{l}\text { Positive } \\
\text { elaboratio } \\
n\end{array}$ & $\begin{array}{l}\text { Neutral, } \\
\text { elaboratio } \\
\text { n }\end{array}$ & $\begin{array}{l}\text { Negative } \\
\text { elaboratio } \\
n\end{array}$ & $\begin{array}{l}\text { Deni } \\
\text { al }\end{array}$ & $\begin{array}{l}\text { Smilin } \\
\mathrm{g}\end{array}$ & $\begin{array}{l}\text { No } \\
\text { respons } \\
\text { e }\end{array}$ \\
\hline 1 & 1 & 1 & 2 & & 5 & 1 & - \\
\hline 2 & 2 & 2 & 3 & & - & 2 & 1 \\
\hline 3 & 1 & 1 & 1 & & 4 & 1 & 2 \\
\hline 4 & 1 & - & 1 & & 1 & 5 & 2 \\
\hline 5 & 1 & - & 1 & & - & 4 & 4 \\
\hline 6 & 1 & - & - & & 3 & 3 & 3 \\
\hline 7 & 2 & 1 & 2 & & 3 & 1 & 1 \\
\hline 8 & 3 & - & 3 & & 3 & - & 1 \\
\hline 9 & 1 & - & 1 & & 1 & 5 & 2 \\
\hline 10 & - & 1 & 2 & & 1 & 2 & 4 \\
\hline Total & 14 & 5 & 16 & - & 21 & 24 & 20 \\
\hline $\begin{array}{l}\text { Percenta } \\
\text { ge }\end{array}$ & $14 \%$ & $5 \%$ & $16 \%$ & - & $21 \%$ & $24 \%$ & $20 \%$ \\
\hline
\end{tabular}

The graphic of the result of students compliment responses in English can be seen as follows: 


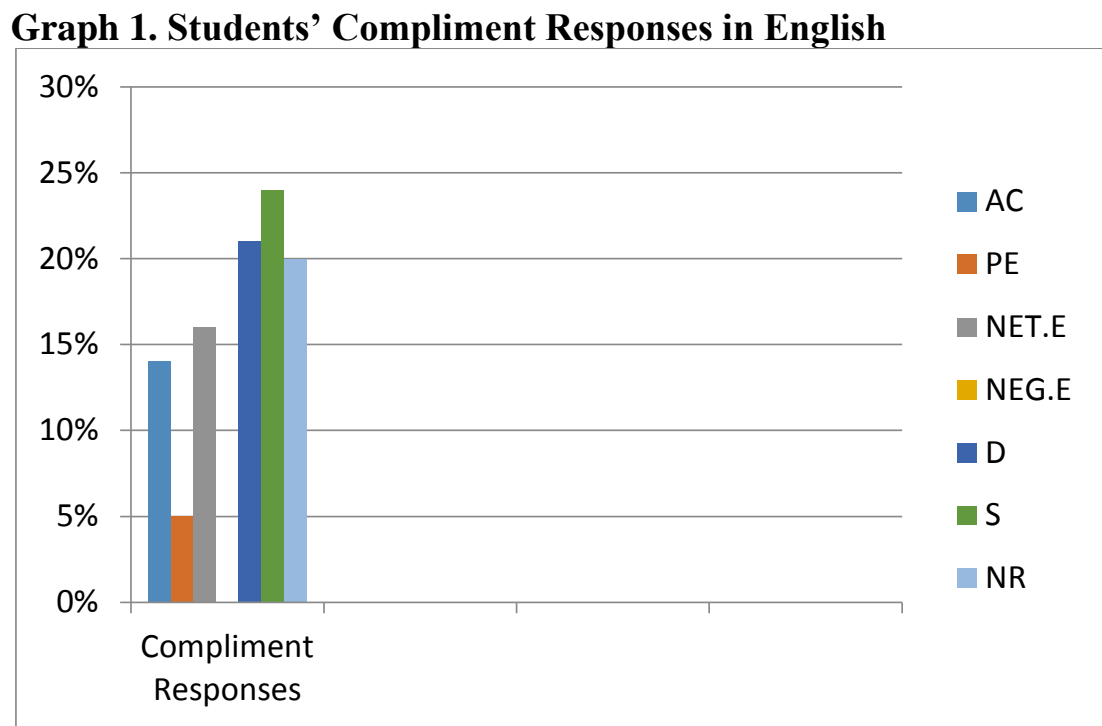

From the table above, it can be seen that from ten students, they used $14 \%$ of acceptance response, $5 \%$ of positive elaboration response, $16 \%$ of neutral elaboration response, $0 \%$ of negative elaboration response, $21 \%$ of denial response, $24 \%$ of smiling response, and $20 \%$ of no response. From the percentage above, we know that there was no negative elaboration response used by the students. The highest and lowest percentage of students compliment responses made by $7^{\text {th }}$ grade students at SMP Negeri 8 Sekayu are smiling and positive elaboration response.

\section{The Differences of Gender in Compliment Responses in English}

The percentage of compliment responses in English made by $7^{\text {th }}$ grade students at SMP Negeri 8 Sekayu based on difference gender can be seen in following table:

Table 7. The Differences of Gender in Compliment Responses in English

\begin{tabular}{|c|c|c|c|c|c|c|c|}
\hline \multirow[t]{2}{*}{ Students } & \multicolumn{7}{|c|}{ Compliments Responses } \\
\hline & $\begin{array}{l}\text { Acceptanc } \\
\mathrm{e}\end{array}$ & $\begin{array}{l}\text { Positive } \\
\text { elaboratio } \\
\mathrm{n}\end{array}$ & $\begin{array}{l}\text { Neutral, } \\
\text { elaboratio } \\
\mathrm{n}\end{array}$ & $\begin{array}{l}\text { Negative } \\
\text { elaboratio } \\
\mathrm{n}\end{array}$ & $\begin{array}{l}\text { Denia } \\
1\end{array}$ & $\begin{array}{l}\text { Smilin } \\
\mathrm{g}\end{array}$ & $\begin{array}{l}\text { No } \\
\text { respons } \\
\text { e }\end{array}$ \\
\hline 1 & 1 & 1 & 2 & & 5 & 1 & - \\
\hline 2 & 2 & 2 & 3 & & - & 2 & 1 \\
\hline 3 & 1 & 1 & 1 & & 4 & 1 & 2 \\
\hline 4 & 1 & - & 1 & & 1 & 5 & 2 \\
\hline 5 & 1 & - & 1 & & - & 4 & 4 \\
\hline \multicolumn{8}{|c|}{ FEMALE (Students 1-5) } \\
\hline Total & 7 & 3 & 8 & & 10 & 13 & 9 \\
\hline $\begin{array}{l}\text { Percentag } \\
\mathrm{e}\end{array}$ & $14 \%$ & $6 \%$ & $16 \%$ & & $20 \%$ & $26 \%$ & $18 \%$ \\
\hline 6 & 1 & - & - & & 3 & 3 & 3 \\
\hline 7 & 2 & 1 & 2 & & 3 & 1 & 1 \\
\hline 8 & 3 & - & 3 & & 3 & - & 1 \\
\hline 9 & 1 & - & 1 & & 1 & 5 & 2 \\
\hline 10 & - & 1 & 2 & & 1 & 2 & 4 \\
\hline
\end{tabular}


Journal of English Teaching Adi Buana, Vol. 05 No. 02, October 2020

\begin{tabular}{|l|l|l|l|l|l|l|l|}
\hline \multicolumn{2}{|l|}{ Male (Students 6-10) } & 7 & 2 & 8 & 11 & 11 & 11 \\
\hline Total & 7 & $4 \%$ & $16 \%$ & & $22 \%$ & $22 \%$ & $22 \%$ \\
\hline $\begin{array}{l}\text { Percentag } \\
\text { e }\end{array}$ & $14 \%$ & $4 \%$ & & & & \\
\hline
\end{tabular}

\begin{tabular}{|l|l|l|l|l|l|l|l|l|}
\hline \multirow{2}{*}{ Students } & \multicolumn{6}{|l|}{ Compliments Responses } \\
\cline { 2 - 9 } & Acceptance & $\begin{array}{l}\text { Positive } \\
\text { elaboration }\end{array}$ & $\begin{array}{l}\text { Neutral, } \\
\text { elaboration }\end{array}$ & $\begin{array}{l}\text { Negative } \\
\text { elaboration }\end{array}$ & Denial & Smiling & $\begin{array}{l}\text { No } \\
\text { response }\end{array}$ & Note \\
\hline Female & $14 \%$ & $6 \%$ & $16 \%$ & & $20 \%$ & $26 \%$ & $18 \%$ & $\mathbf{1 0 0 \%}$ \\
\hline Male & $14 \%$ & $4 \%$ & $16 \%$ & & $22 \%$ & $22 \%$ & $22 \%$ & $\mathbf{1 0 0} \%$ \\
\hline
\end{tabular}

The graphic of the result of students compliment responses in English based on gender can be seen as follows:

\section{Graph 2. Students' Compliment Responses in English Based On Gender}

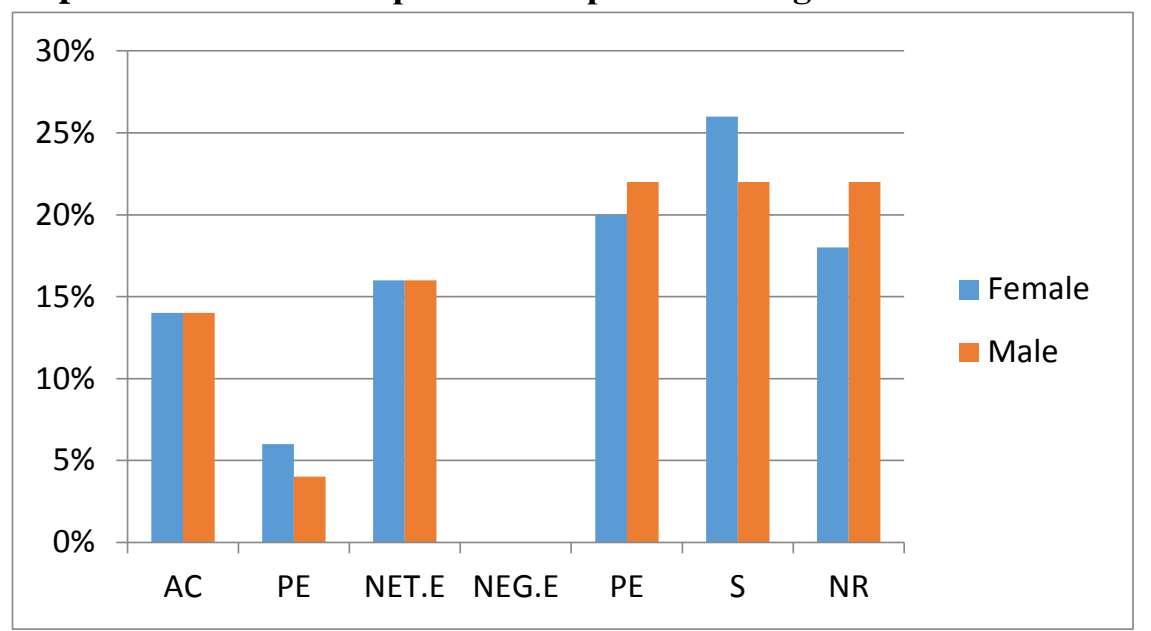

Graph 2 showed the differences of students compliment responses in English. The similarity of compliment responses in English made by $7^{\text {th }}$ grade students at SMP Negeri 8 Sekayu is acceptance (14\%), neutral elaboration (16\%), and negative elaboration response $(0 \%)$. The significant difference of compliment responses in English made by $7^{\text {th }}$ grade students at SMP Negeri 8 Sekayu based on gender: 1) female had highest percentage in positive elaboration and smiling response; and 2) male had highest percentage in denial and no response.

1. Female $(6 \%)$ had highest percentage in positive elaboration response than male $(4 \%)$.

2. Female $(26 \%)$ had highest percentage in smiling response than male (22 $\%)$.

3. Male $(22 \%)$ had highest percentage in denial response than female $(20 \%)$.

4. Male $(22 \%)$ had highest percentage in no response than female $(18 \%)$.

Based on the findings, students' compliment responses in English were dominated by smiling responses. This finding is similar with Purnomo (2015) who 
stated that smiling response was one of the response that done by the students. However, those findings about compliments were also supported by Falasi, (2006) Han, (1992). They found about types of compliments. Meanwhile, the findings about the differences of gender in compliment responses in English is also dominated by female in smiling responses rather than male. The findings of this study showed the politeness of the students to the teacher. Morales (2010) stated that smiling response is one of the politeness way to other people.

\section{CONCLUSIONS}

From the results and discussion above, it can be concluded that:

1. Compliment responses in English made by $7^{\text {th }}$ grade students at SMP Negeri 8 Sekayu are: acceptance, positive elaboration, neutral elaboration, denial, smiling, and no response.

2. The similarity of compliment responses in English made by $7^{\text {th }}$ grade students at SMP Negeri 8 Sekayu: acceptance (16\%), neutral elaboration $(16 \%)$, and negative elaboration response $(0 \%)$.

3. The significant difference of compliment responses in English based on gender: 1) female had highest percentage in positive elaboration and smiling response; and 2) male had highest percentage in denial and no response.

\section{REFERENCES}

Cedar, P. (2006).Thai and American responses to compliments in English. The Linguistic Journal, 1(2), 6-28. Retrieved from http://www.linguisticsjournal.com/TLJ\%20June\%202006.pdf.

Falasi, H. A. (2006). Just say "thank you": A study of compliment responses. Linguistic Journal, 2(1), 28-41. Retrieved from http://www.linguisticsjournal.com/April_2007_haf.php.

Farkhan, Muhammad. Proposal Penelitian Bahasa dan Sastra. Jakarta: Cella, 2007.

Han, C. H. (1992). A comparative study of compliment responses: Korean females in Korean interactions and in English interactions. WPEL, 8(2), 17-31. Retrieved from http://www.gse.upenn.edu/wpel/sites/gse.upenn.edu.wpel/files/archives/v8/v 8n2_han.pdf.

Hiroko, M. (2002).A cross-cultural study of compliment responses in American English and Japanese. 商学論集, 71(1), 53-66.Retrieved from http://ir.lib.fukushima-u.ac.jp/dspace/bitstream/10270/660/1/3-385.pdf.

Kim, H.J. (2002). A study of compliments across cultures: The effect of sociolinguistic transfer on EFL leaners. Retrieved from http://www.paaljapan.org/resources/proceedings/PAAL8/pdf/pdf015.pdf.

Kridalaksana, Harimurti. Kamus Linguistik. Jakarta: PT.Gramedia, 1982.

Spolsky, Bernard. Sociolinguistics. New York: Oxfor University Press, 1998.

Morales, R. C. (2010). Compliment responses across gender in Philippine context. 3L: The Southest Asian Journal of English Language Studies, 18(1), 47-60. 
Retrieved from http://journalarticle.ukm.my/4063/1/7Rodrigo\%2520Concepcion\%2520Morales.pdf.

Nasution. 2003. Penelitian Survey. Bandung: Gramedia Pustaka.

Nurizah.(2009). A comparison between Malay and American responses to compliments in English. Fakulti Pendidikan: Universiti Teknologi Malaysia. Retrieved from http://eprints.uthm.edu.my/1691/1/NURIZAH_MD_NGADIRAN.pdf.

Nurul Zuriah. 2007. Metodologi Penelitian Sosial dan Pendidikan. Jakarta: Bumi Aksara.

Purnomo, A.P. (2015). Compliment and compliments responses used by english teacher association of senior high school in Pacitan. Unpublished Thesis. English Department of Postgraduate Program of Muhammadiyah University of Surakarta.

Riduwan.(2011). Belajar mudah penelitian untuk guru-karyawan dan peneliti muda. Bandung: CV. Alfabeta.

Setiadi, Bambang. 2006. Metode Penelitian Untuk Pengajaran Bahasa Asing. Yogyakarta: Graha Ilmu.

SMP Negeri 8 Sekayu. Data Siswa dan Nilai Siswa Tahun Ajaran 211/2012. Musi Banyausin: Dinas Pendidikan Nasional Kabupaten Musi Banyuasin.

Wang, Y. F., \& Tsai, P. H. (2000).An emperical study on compliment and compliment responses in Taiwan mandarin conversation. Retrieved from http://ai.nknu.edu.tw/nknutc/english/papers/Compliment\%20(Concentric).p df.

Yuhuan, W. (1997).Different responses to compliments in Chinese and English.Retrieved from http://www.celea.org.cn/pastversion/lw/pdf/wangyuhuan.pdf.

Tripod. 1999. Sex as a Factor in Complimenting Behavior among Marrakeshi Men and Women. Retrieved from http://aisaoui.tripod.com/ais2/id6.html. 